\title{
Total synthesis of targretin via palladium catalyzed cross- coupling reaction of a vinyl organozinc intermediate
}

\author{
Palimécio G. Guerrero Jr., ${ }^{\text {a }}$ Paulo R. de Oliveira, ${ }^{a}$ Adriano C. M. Baroni, ${ }^{b}$ Francisco \\ A. Marques, ${ }^{c}$ Gabriela R. Hurtado ${ }^{d}$ and Miguel J. Dabdoub ${ }^{e}$ \\ ${ }^{a}$ Department of Chemistry and Biology, Federal University of Technology, UTFPR, Curitiba, PR, Brazil \\ ${ }^{\mathrm{b}}$ Department of pharmacy-biochemistry, Federal University of Mato Grosso do Sul, UFMS, Campo Grande, \\ MS, Brazil \\ ${ }^{c}$ Department of Chemistry, Federal University of Parana, UFPR, Curitiba, PR, Brazil \\ ${ }^{d}$ Department of Chemistry, Federal University of Mato Grosso do Sul, UFMS, Campo Grande, MS, Brazil \\ e Department of Chemistry, São Paulo University, USP, Ribeirao Preto, SP, Brazil
}

*pali@utfpr.edu.br, paligimenes@yahoo.com.br

Keywords: targretin, anticancer, synthesis, paladdium-cross coupling reaction

\section{INTRODUCTION}

In the last two decades, retinoids as isotretinoin, etretinate and acitretin have been utilized in treatment of primary cutaneous T-cell lymphoma (CLTC) showing modest response in rats. ${ }^{1}$ However, the bexarotene (targretin $\left.{ }^{\circledR}\right) 1$ emerged as a potent and highly selective ligand for the retinoid $X$ receptors (RXRs) applied in human patients to combat the CLTC, which have become a serious public health problem.

\section{RESULTS AND DISCUSSION}

The oral targretin was approved by the Food and Drug Administration (FDA) in 1999 and in 2002 in Europe. Actually it is widely used for treatment of breast cancer, ${ }^{2}$ mycosis fungoides ${ }^{1}$ and Sézary syndrome. ${ }^{1}$

Considering their pharmacological activities, we described a short and efficient total synthesis of targretin which was started using the cross coupling reaction involving the 7-bromo-1,2,3,4,-tetrahydro1,1,4,4,6-pentamethyl naftalene (obtained following experimental procedure described in the literature) ${ }^{3}$ 2 and 3-dimethyl-2-propyn-1-ol 3, furnishing the disubstituted acetylene 4. Next, the retro-Favorsky elimination of $\mathbf{4}$ resulted in the terminal acetylene $\mathbf{5}$ which was hydrometallated ${ }^{4}$ with DIBAL$\mathrm{H} / \mathrm{Ni}$ (ddp) $\mathrm{Cl}_{2}$, followed by $\mathrm{Te} / \mathrm{Al}$ transmetallation affording the $\alpha$-vinyl alana 6 , which was reacted with $\mathrm{C}_{4} \mathrm{H}_{9} \mathrm{TeBr}$ leading to the 1,1,-disubstituted vinyl telluride 7. The key step in the synthesis of targretin involved the $\mathrm{Pd}\left(\mathrm{PPh}_{3}\right)_{4} / \mathrm{Cul}$ cross coupling catalyzed reaction of aryl organozinc compound $\mathbf{8}$ (prepared in situ via Te/Zn transmetallation from 7$)^{5}$ with the aryl iodide $\mathbf{9}$ to give the targretin-oxazoline 10 .

Finally, the desprotection of 10 under concentrated $\mathrm{HCl}$ furnished the free carboxylic acid targretin 1 in $23 \%$ overall yield from disubstituted acetylene 4 (Scheme 1).
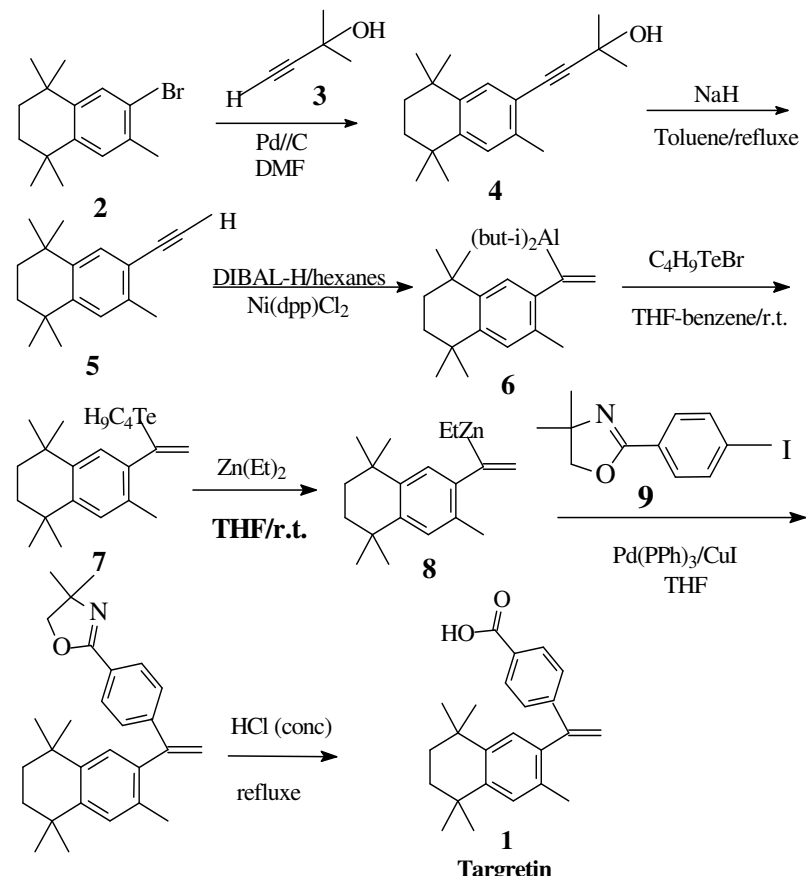

10

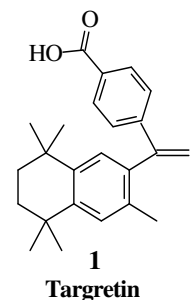

Scheme 1

\section{CONCLUSION}

We described here a novel and efficient total synthesis of the anticancer targretin.

\section{ACKNOWLEDGEMENTS}

CNPq, CAPES and Fundação Araucária

\section{REFERENCES}

${ }^{1}$ Abbott, R. R.; Whittaker, S.L. ; Morris, R.; Scarisbrick, J. J. Brit. J. Dermat. 2009, 160, 1299.

${ }^{2}$ Howe, L. R. Clin. Cancer Res. 2007, 13, 5983.

${ }^{3}$ Boehm, M.; Zhang, L.; Badea.B. A. J.Med. Chem.1994, 37, 2930.

${ }^{4}$ Gao, F.; Hoveyda, A. H. J. Am. Chem. Soc. 2010, 132,10961.

${ }^{5}$ Dabdoub,M. J. Dabdoub, V. B.; Marino, J. P. Tetrahedron Lett. 2000, 41,433 . 